\title{
High rate of increased level of plasma Angiotensin II and its gender difference in COVID-19: an analysis of 55 hospitalized patients with COVID-19 in a single hospital, WuHan, China
}

$\mathrm{Na}$ Liu

Wuhan University Renmin Hospital

Yan Hong

Guangzhou Women and Children's Medical Center

Ren-Gui Chen

Wuhan University Renmin Hospital

Heng-Mei Zhu ( $\sim$ zhuhengmei00@163.com )

the First Affiliated Hospital of Nanchang University https://orcid.org/0000-0001-7587-1044

Original investigation

Keywords: 2019 Novel coronavirus disease(COVID-19), Angiotensin-converting enzyme 2 (ACE2), Angiotensin II(Angll), gender differences

Posted Date: August 19th, 2020

DOI: https://doi.org/10.21203/rs.3.rs-51770/v1

License: (a) This work is licensed under a Creative Commons Attribution 4.0 International License. Read Full License 


\section{Abstract}

Background: 2019 Novel coronavirus disease (COVID-19) is turning into a pandemic globally lately. There were few reports illustrated the expression of Angiotensin II (Angll) in COVID-19. This study aimed to demonstrate the expression of Angll in COVID-19 and how it correlated to the disease.

Methods and Results: We enrolled 55 patients with COVID-19 admitted to Renmin Hospital of Wuhan University from January 21 st to February 21 st, 2020. Demographic data were collected upon admission. COVID-19 nuclear acid, plasma Angll, Renin and aldosterone in the lying position without sodium restriction, and other laboratory indicators were together measured by the laboratory department of our hospital. Of the 55 patients with COVID-19, 34(61.8\%) had an increased level of Angll. The severity of COVID-19 and male is positively related with the level of Angll. The level of blood lymphocyte, PCT, ALT, and AST were remarkably severe with those of normal level of Angll $(P<0.05)$. CD4/CD8 cells ratio was significantly higher than those of normal level of Angll $(P<0.05)$. The results of binary logistic regression analysis showed that the severity of COVID-19 $(\mathrm{OR}=4.123)$ and $\mathrm{CD} 4 / \mathrm{CD} 8$ ratio(OR=4.050) were the co-directional impact factor while female $(\mathrm{OR}=0.146)$ was inverse impact factor of elevated Angll level.

Conclusion: High rate of increased level of Angll and its gender differences were detected in COVID-19 patients. Elevated Angll level were correlated with the severity of COVID-19 and CD4/CD8 ratio.

\section{Background}

2019 Novel coronavirus disease(COVID-19) is rampant in China since December 2019 and spread worldwide gradually $^{1-5}$. Up to March 17th, a total of 179111 confirmed cases and 7,426 dead cases were reported worldwide according to WHO updates ${ }^{5}$. Angiotensin-converting enzyme 2 (ACE2) is identified as an important functional receptor for SARS-Cov-2 ${ }^{6-7}$. The host receptor ACE2 degrades after binding to SARS-Cov-2, leading to ACE2 loss and prompting the target oragns injury ${ }^{6}$. ACE2 and ACE are homologues with opposite functions in the renin-angiotensin system ${ }^{8-9}$. ACE converts angiotensin I into a vital vasoactive peptide called angiotensin II(AngII), whereas ACE2 hydrolyzes Angll into a series of vasodilators. Theoretically, the loss of ACE2 may reduce degradation of Angll and cause vasoconstriction and oxidative stress. Recently『a small sample study found that plasma angiotensin II levels were significantly increased and linearly associated to viral load and lung injury in COVID-1 $1{ }^{10}$. However, the sample size was too small to observe the exact relationship with the disease. Therefore, this study aimed to demonstrate the expression of angiotensin II in COVID-19 and how it correlated to the disease.

\section{Methods}

\section{Study Design and Participants $\llbracket$}

This was a single center, retrospectively and observational analysis. We enrolled 55 patients with COVID-19 admitted to Renmin Hospital of Wuhan University from January 21 st to February 21st, 2020. All patients hadn't taken any angiotensin-converting enzyme (ACE) inhibitors, angiotensin II type 1 receptor (AT1R) blockers, and diuretics two weeks before and during hospitalization. The diagnosis of hypertension and diabetes were based 
on 2018 ESC/ESH Guidelines for the management of arterial hypertension and 2019 ESC Guidelines on diabetes, pre-diabetes, and cardiovascular diseases developed incollaboration with the EASD.COVID-19 was diagnosed based on the Diagnosis and Treatment Scheme for New Coronavirus Pneumonia (Pilot Edition 5区 Revised version) published by the National Health Commission of China ${ }^{11}$. A confirmed case with COVID-19 was defined as a positive result to real-time reverse-transcriptase polymerase-chain-reaction (RT-PCR) assay for nasal and throat swab specimens. All patients had imaging pneumonia. Critically ill COVID-19 was defined as meeting either one of the flowing criteria: 1) Respiratory distress with respiratory rate more than 30 times/min; 2) Oxygen saturation $\leq 93 \%$ in resting state; 3$) \mathrm{PaO} 2 / \mathrm{FiO} 2 \leq 300 \mathrm{mmHg} \otimes(1 \mathrm{mmHg}=0.133 \mathrm{kPa}) .4)$ Respiratory failure requires mechanical ventilation; 5) Shock; 6) Combining other organ failures requires ICU monitoring and treatment. The study was approved by the ethics committee of Renmin Hospital of Wuhan University(Application ID\&[WDRY2020-K114]).

\section{Clinical and laboratory Data Collection}

Demographic data including age, gender, and previous medical history were collected. Laboratory assessments consisting of plasma Angll, renin and aldosterone in the lying position without sodium restriction, complete blood count, blood chemistry, coagulation test, liver and renal function, electrolytes, C-reactive protein, procalcitonin, lactate dehydrogenase and creatine kinase were tested by the laboratory department.

\section{Statistical Analysis}

All statistical analyses were performed by SPSS for mac software, version 23.0. Continuous variables were presented as the means and standard deviations or medians and interquartile ranges (IQR) as appropriate. Categorical variables were summarized as the counts and percentages in each category. Independent-Samples T test or the Mann-Whitney U test were applied to continuous variables, chi-square tests and Fisher's exact tests were used for categorical variables as appropriate. Predictors of Angll anomaly were analyzed by logistic regression. A value of $p<0.05$ was considered statistically significant.

\section{Results}

By Feb 21st, 2020, 55 confirmed cases of COVID-19 were included in this study. All of them had data on plasma Angll, renin and aldosterone in the lying position without sodium restriction. 34(61.8\%) cases had an increased level of Angll while most patients had normal levels of renin and aldosterone (showed in Table 1). The critically ill patients had higher level of Angll than the non-critically ill patients (showed in Table 2). 
Table 1

the baseline value of RAS system in COVID-19 patients

\begin{tabular}{|llll|}
\hline RAS system parameter & Normal Range & Total $(\mathbf{N}=\mathbf{5 5})$ & Abnormality, N(\%) \\
\hline Angll(pg/ml, IQR) & $25-129$ & $134.2(117.8,155.3)$ & $34(61.8)$ \\
\hline Renin(pg/ml, IQR) & $4-24$ & $10.9(6.3,16.9)$ & $11(20)$ \\
\hline ALD(pg/ml, IQR) & $10-160$ & $129.5(112,149.8)$ & $9(16.4)$ \\
\hline AARR(IQR) & $/$ & $12.3(7.6,19.2)$ & $/$ \\
\hline Legend: Ang Il: angiotensin II, ALD: aldosterone, AARR: aldosterone/ Renin ratio \\
\hline
\end{tabular}

Table 2

Comparison of RAS system between non-critically ill and critically ill patients with COVID-19

\begin{tabular}{|c|c|c|c|c|c|}
\hline RAS system & $\begin{array}{l}\text { Normal } \\
\text { Range }\end{array}$ & Total $(\mathrm{N}=55)$ & $\begin{array}{l}\text { Non-critically ill } \\
\text { group }(n=32)\end{array}$ & $\begin{array}{l}\text { critically ill group(n } \\
=23 \text { ) }\end{array}$ & $\begin{array}{l}P \\
\text { value }\end{array}$ \\
\hline $\begin{array}{l}\text { Angll(pg/ml, } \\
\text { IQR) }\end{array}$ & $\begin{array}{l}25- \\
129\end{array}$ & $134.2(117.8,155.3)$ & $127.4(93.5,145.6)$ & $147.4(131.5,169.5)$ & $0.009 *$ \\
\hline $\begin{array}{l}\text { Renin(pg/ml, } \\
\text { IQR) }\end{array}$ & $4-24$ & $10.9(6.3,16.9)$ & $10.2(5.8,16.2)$ & $14.7(6.5,19.7)$ & 0.232 \\
\hline $\begin{array}{l}\text { ALD(pg/ml, } \\
\text { IQR) }\end{array}$ & $\begin{array}{l}10- \\
160\end{array}$ & 129.5(112,149.8) & 133.4(115.1,168.1) & $115.9(104.8,135.7)$ & 0.050 \\
\hline AARR(IQR) & / & $12.3(7.6,19.2)$ & 14.1(10.1,21.5) & $9.1(6.2,18.7)$ & $0.028 *$ \\
\hline
\end{tabular}

To further analyze the demographic, clinical and laboratory characteristics of the patients with increased Angll level, we divided the patients into the Angll increased group and the Angll normal group. No difference was seen in renin and aldosterone values between the two groups (showed in Table 3). To our interest, as shown in Table 4, the patients with increased level of Angll were more severe than those with normal level of Angll [18(52.9\%)vs5(23.8\%), p = 0.033]. Significant gender differences were found between the two groups. In addition, there was no significant difference in the history of hypertension and the use of vasoactive drugs such as norepinephrine and dopamine in the two groups. 
Table 3

Comparison of RAS system between COVID-19 patients grouped by Ang II level

\begin{tabular}{|c|c|c|c|c|c|}
\hline RAS system & $\begin{array}{l}\text { Normal } \\
\text { Range }\end{array}$ & Total $(\mathrm{N}=55)$ & $\begin{array}{l}\text { Ang II increased } \\
\text { group }(n=34)\end{array}$ & $\begin{array}{l}\text { Ang II } \\
\text { normal } \\
\text { group(n= 21) }\end{array}$ & $\begin{array}{l}\mathrm{P} \\
\text { value }\end{array}$ \\
\hline $\begin{array}{l}\text { Angll(pg/ml, } \\
\text { IQR) }\end{array}$ & $\begin{array}{l}25- \\
129\end{array}$ & $134.2(117.8,155.3)$ & 149.7(137.8,165.1) & $99.4(84.5,119.1)$ & 0.000 \\
\hline $\begin{array}{l}\text { Renin(pg/ml, } \\
\text { IQR) }\end{array}$ & $4-24$ & $10.9(6.3,16.9)$ & $11 \cdot 1(6 \cdot 0,19.5)$ & $10(6.5,16.9)$ & 0.842 \\
\hline $\begin{array}{l}\text { ALD }(p g / m l, \\
\text { IQR) }\end{array}$ & $\begin{array}{l}10- \\
160\end{array}$ & $129.5(112,149.8)$ & $133.4(112.4,142.1)$ & $121.8(106.9,163.5)$ & 0.591 \\
\hline AARR(IQR) & / & $12.3(7.6,19.2)$ & $12.3(7.0,19.9)$ & $12.4(9.3,19.5)$ & 0.665 \\
\hline
\end{tabular}

Table 4

Comparison of Demographic and clinical characteristic between COVID-19 patients grouped by Ang II level

\begin{tabular}{|c|c|c|c|c|}
\hline $\begin{array}{l}\text { Demographic and clinical } \\
\text { characteristics }\end{array}$ & $\begin{array}{l}\text { Total } \\
(\mathrm{N}=55)\end{array}$ & $\begin{array}{l}\text { Ang Il increased group(n } \\
=34)\end{array}$ & $\begin{array}{l}\text { Ang II } \\
\text { normal } \\
\text { group(n= 21) }\end{array}$ & $\begin{array}{l}P \\
\text { value }\end{array}$ \\
\hline Gender female, n(\%) & $20(36.4)$ & $7(12.7)$ & $13(21.7)$ & $0.002^{*}$ \\
\hline Age(year, IQR) & $53(45,66)$ & $56(44.75,66.5)$ & $52(45.5,67)$ & 0.0822 \\
\hline History of chronic disease, $n(\%)$ & $25(45.5)$ & 18(32.7) & $7(12.7)$ & 0.156 \\
\hline History of hypertension, n(\%) & $16(29.1)$ & $13(23.6)$ & $3(5.5)$ & 0.057 \\
\hline History of diabetes, n(\%) & $8(14.5)$ & $7(12.7)$ & $1(1.8)$ & 0.136 \\
\hline Newly-onset hypertension, n(\%) & $10(18.2)$ & $6(10.9)$ & $4(7.3)$ & 1.0 \\
\hline Systolic pressure(mmHg, IQR) & $129(122,141)$ & $134(122,141)$ & $126(123,140)$ & 0.640 \\
\hline Diastolic pressure(mmHg, IQR) & $81(76,90)$ & $80(73,91)$ & $83(72,96)$ & 0.641 \\
\hline The severity of COVID-19 & - & - & - & - \\
\hline Non-critically ill, n(\%) & $32(58.2)$ & $16(29.1)$ & $16(29.1)$ & $0.033^{*}$ \\
\hline Critically ill, n(\%) & $23(41.8)$ & $18(32.7)$ & $5(9.1)$ & - \\
\hline Usage of vasoactive drugs, $n(\%)$ & $7(12.7)$ & $5(9.1)$ & $2(3.6)$ & 0.696 \\
\hline \multicolumn{5}{|c|}{$\begin{array}{l}\text { Legend- Critically ill COVID-19 was defined as meeting either one of the flowing criteria: } 1 \text { ) Respiratory } \\
\text { distress with respiratory rate more than } 30 \text { times/min; } 2 \text { ) Oxygen saturation } \leq 93 \% \text { in resting state; } 3 \text { ) } \\
\text { PaO2/FiO2 } \leq 300 \mathrm{mmHg}(1 \mathrm{mmHg}=0.133 \mathrm{kPa}) .4 \text { ) Respiratory failure requires mechanical ventilation; } 5) \\
\text { Shock; } 6 \text { ) Combining other organ failures requires ICU monitoring and treatment. }\end{array}$} \\
\hline
\end{tabular}


As presented in Tables 5-6, there were statistical difference in the level of blood

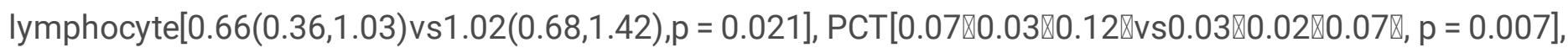

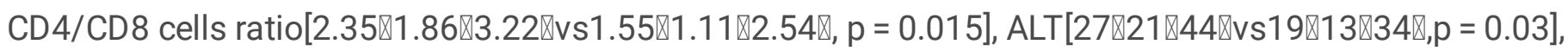
AST[24.5(18.5,36)vs18(14,22.5),p = 0.028], CD3 + CD8 + cells [128(51,206)vs218 $(123,322), p=0.016], C D 3+$ CD8 + cells proportion $[20.1(14,25.6) v s 25.4(20.9,35.7), p=0.011], C D 56+C D 16+C D 3$ - cells $[81(56,102) / 111(66,171) p=0.031]$ between the Angll increased group and the Angll normal group. The rate of Lymphopenia [27(79.4\%)vs11(52.4\%), $p=0.035$ ] were remarkably higher in Patients with elevated Angll level. 
Table 5

Comparison of laboratory assessments between COVID-19 patients grouped by Ang II level

\begin{tabular}{|c|c|c|c|c|c|}
\hline $\begin{array}{l}\text { Laboratory } \\
\text { assessments }\end{array}$ & $\begin{array}{l}\text { Normal } \\
\text { Range }\end{array}$ & Total $(\mathrm{N}=55)$ & $\begin{array}{l}\text { Ang II increased } \\
\text { group }(n=34)\end{array}$ & $\begin{array}{l}\text { Ang II } \\
\text { normal } \\
\text { group(n= 21) }\end{array}$ & $\begin{array}{l}\mathrm{P} \\
\text { value }\end{array}$ \\
\hline WBC(109/L,IQR) & $3.5-9.5$ & $6.76(5.25,9.36)$ & $6.98(4.77,10.06)$ & $6.67(5.67,8.23)$ & 0.952 \\
\hline Ly $\left(10^{9} / \mathrm{L}, \mathrm{IQR}\right)$ & $1.1-3.2$ & $0.74(0.49,1.19)$ & $0.66(0.36,1.03)$ & $1.02(0.68,1.42)$ & $0.021 *$ \\
\hline $\mathrm{HB}(\mathrm{g} / \mathrm{L}, \mathrm{IQR})$ & $130-175$ & $128(114,142)$ & $127.5(112,142.8)$ & $128(114,140)$ & 0.959 \\
\hline $\operatorname{PLT}\left(10^{9} / \mathrm{L}, \mathrm{IQR}\right)$ & $125-350$ & $198(142,263)$ & $189(122.3,263.8)$ & $238(171,274)$ & 0.225 \\
\hline $\mathrm{CRP}(\mathrm{mg} / \mathrm{L}, \mathrm{IQR})$ & $0-8$ & $\begin{array}{l}7.73(2.88- \\
26.36)\end{array}$ & $11.2(3.67,44.99)$ & $7.03(1.53,21.20)$ & 0.253 \\
\hline PCT (ng/mL,IQR) & $0-0.09$ & $0.06(0.03,0.1)$ & $0.07(0.05,0.12)$ & $0.03(0.02,0.07)$ & $0.007 *$ \\
\hline $\operatorname{ALT}(\mathrm{U} / \mathrm{L}, \mathrm{IQR})$ & $9-50$ & $26(18,38)$ & $27(21,44.3)$ & $19(13,34)$ & $0.030 *$ \\
\hline AST (U/L,IQR) & $15-40$ & $21(16,32)$ & $24.5(18.5,36)$ & $18(14,22.5)$ & $0.028 *$ \\
\hline ALB(g/L,IQR) & $40-55$ & $33.9(30.1,37.4)$ & $33.6(30.1,36.1)$ & $36(29.8,38.9)$ & 0.253 \\
\hline $\mathrm{BUN}(\mathrm{mmol} / \mathrm{L}, \mathrm{IQR})$ & $3.2-8.0$ & $4.9(3.0,7.5)$ & $4.95(3.1,8.38)$ & $4.3(2.85,6.45)$ & 0.287 \\
\hline sCr(umol/L,IQR) & $\begin{array}{l}\text { Male:57- } \\
97 \\
\text { Female:41- } \\
81\end{array}$ & $60(48.2,67.4)$ & $61.3(54.6,70.3)$ & $55.2(45.7,65.8)$ & 0.203 \\
\hline $\mathrm{LDH}(\mathrm{U} / \mathrm{L}, \mathrm{IQR})$ & $120-250$ & $214(179,354)$ & $244(188.3,400)$ & $201(176.5,258)$ & 0.057 \\
\hline CK(U/L,IQR) & $50-310$ & $39(26,57)$ & $38(26.8,59)$ & $40(25,59)$ & 0.972 \\
\hline $\mathrm{Na}(\mathrm{mmol} / \mathrm{L}, \mathrm{IQR})$ & $137-147$ & $135(132.1,138.7)$ & $134.9(131.6,137.5)$ & $136.3(134,138.9)$ & 0.194 \\
\hline $\mathrm{K}(\mathrm{mmol} / \mathrm{L}, \mathrm{IQR})$ & $3.5-5.3$ & $4.01(3.70,4.61)$ & $3.99(3.64,4.62)$ & $4.2(3.82,4.63)$ & 0.550 \\
\hline $\mathrm{DD}(\mathrm{mg} / \mathrm{L}, \mathrm{IQR})$ & $0.01-0.55$ & $1.96(0.69,4.92)$ & $3.46(0.82,6.56)$ & $1.2(0.63,30.2)$ & 0.121 \\
\hline APTT(s,IQR) & $25-31.3$ & $26.5(23.8,29.1)$ & $26.1(24.0,28.1)$ & $26.8(23.5,30.2)$ & 0.808 \\
\hline $\begin{array}{l}\text { Urine protein } \\
\text { positive, } n(\%)\end{array}$ & / & $7(12.7)$ & $6(10.9)$ & $1(1.8)$ & 0.232 \\
\hline $\begin{array}{l}\text { Urine RBC } \\
\text { positive, } n(\%)\end{array}$ & / & $3(5.35)$ & $2(3.64)$ & $1(1.8)$ & 1.0 \\
\hline Ly $<1.1, n(\%)$ & / & $38(69.1)$ & $27(49.1)$ & $11(20)$ & $0.035^{\star}$ \\
\hline $\mathrm{PCT}>0.09, \mathrm{n}(\%)$ & I & 15(27.3) & 12(21.8) & $3(5.5)$ & 0.123 \\
\hline
\end{tabular}




\begin{tabular}{|c|c|c|c|c|c|}
\hline $\begin{array}{l}\text { Laboratory } \\
\text { assessments }\end{array}$ & $\begin{array}{l}\text { Normal } \\
\text { Range }\end{array}$ & Total $(\mathrm{N}=55)$ & $\begin{array}{l}\text { Ang II increased } \\
\text { group }(n=34)\end{array}$ & $\begin{array}{l}\text { Ang II } \\
\text { normal } \\
\text { group(n }\end{array}$ & $\begin{array}{l}\mathrm{P} \\
\text { value }\end{array}$ \\
\hline \multicolumn{6}{|c|}{$\begin{array}{l}\text { Legend: Ly: Lymphocyte, HB: Hemoglobin, PLT: Platelet count, CRP: C-reactive protein, PCT: } \\
\text { Procalcitonin,BUN: Blood urea nitrogen, sCr: serum creatinine, ALT :Aspartate aminotransferase, AST: } \\
\text { Alanine aminotransferase, ALB: albumin, LDHDlactate dehydrogenase, CK:Creatinine kinase, DD:D-dimer, } \\
\text { APTT: Activated partial thromboplastin time }\end{array}$} \\
\hline
\end{tabular}

Table 6

Comparison of Lymphocyte classification between COVID-19 patients grouped by Ang II level

\begin{tabular}{|c|c|c|c|c|c|}
\hline Lymphocyte marker & $\begin{array}{l}\text { Normal } \\
\text { Range }\end{array}$ & Total $(\mathrm{N}=46)$ & $\begin{array}{l}\text { Ang II increased } \\
\text { group }(n=27)\end{array}$ & $\begin{array}{l}\text { Ang II } \\
\text { normal } \\
\text { group }(n=19)\end{array}$ & $\begin{array}{l}\mathrm{P} \\
\text { value }\end{array}$ \\
\hline CD3 + count (/uL,IQR) & $\begin{array}{l}1185- \\
1901\end{array}$ & $561(274.3,776.3)$ & $439(178,741)$ & $669(448,841)$ & 0.073 \\
\hline CD3+ (\%,IQR) & $\begin{array}{l}64.19- \\
75.77\end{array}$ & $68.9(60.75,77.93)$ & $69.1(55.5,82.1)$ & $68.7(66.4,77.6)$ & 0.510 \\
\hline $\begin{array}{l}\text { CD3 + CD4 + count } \\
\text { (/uL,IQR) }\end{array}$ & $\begin{array}{l}561- \\
1137\end{array}$ & $335.5(157.8,488.3)$ & $298(122,488)$ & $390(234,504)$ & 0.160 \\
\hline $\mathrm{CD} 3+\mathrm{CD} 4+(\%, \mathrm{IQR})$ & $\begin{array}{l}30.09- \\
40.41\end{array}$ & $44.9(34.4,51.1)$ & $47.4(34.5,56.2)$ & $41.2(34,47.9)$ & 0.212 \\
\hline $\begin{array}{l}\text { CD3 + CD } 8+\text { count } \\
\text { (/uL,IQR) }\end{array}$ & $\begin{array}{l}404- \\
754\end{array}$ & $163(74.8,243.5)$ & $128(51,206)$ & $218(123,322)$ & $0.016 *$ \\
\hline $\mathrm{CD} 3+\mathrm{CD} 8+(\%, \mathrm{IQR})$ & $\begin{array}{l}20.74- \\
29.42\end{array}$ & $23.0(17.1,29.3)$ & $20.1(14,25.6)$ & $25.4(20.9,35.7)$ & $0.011 *$ \\
\hline CD4+/CD8+ & $\begin{array}{l}1.36- \\
2.61\end{array}$ & $2.05(1.47,2.55)$ & $2.35(1.86,3.22)$ & $1.55(1.11,2.54)$ & $0.015^{\star}$ \\
\hline $\begin{array}{l}\text { CD56 + CD 16 + CD3- } \\
\text { count (/uL,IQR) }\end{array}$ & $\begin{array}{l}175- \\
567\end{array}$ & $86.5(62.8,125.5)$ & $81(56,102)$ & $111(66,171)$ & $0.031 *$ \\
\hline $\begin{array}{l}\text { CD56 + CD 16 + CD3- } \\
(\%, I Q R)\end{array}$ & $\begin{array}{l}10.04- \\
19.78\end{array}$ & 13.75(7.95,20.73) & $12.9(7,24)$ & $13.8(8.3,18.9)$ & 0.832 \\
\hline $\begin{array}{l}\text { CD19+ CD3- count } \\
\text { (/uL,IQR) }\end{array}$ & $\begin{array}{l}180- \\
324\end{array}$ & $91(55.8,155.8)$ & $73(46,131)$ & $134(59,170)$ & 0.072 \\
\hline CD19 + CD3- (\%,IQR) & $\begin{array}{l}10.12- \\
15.42\end{array}$ & $13.8(8.5,21.7)$ & $14.1(5.7,24.4)$ & $13.5(9.6,19.5)$ & 0.422 \\
\hline \multicolumn{6}{|c|}{$\begin{array}{l}\text { Legend: } C D \text { : cluster of differentiation, } C D 3+\text { count: } C D 3 \text { positive cells count, } C D 3+C D 4+\text { count: } C D 3 \\
\text { positive } C D 4 \text { positive cells count, } C D 3+C D 8+\text { count: } C D 3 \text { positive } C D 8 \text { positive cells count, } C D 4+/ C D 8+: \\
\text { CD4+/CD8 + ratio, } C D 56+C D 16+C D 3-\text { count: } C D 56 \text { positive } C D 16 \text { positive } C D 3 \text { negtive cells count, } C D 19+ \\
\text { CD3- count: CD } 19 \text { positive } C D 3 \text { negtive cells count. }\end{array}$} \\
\hline
\end{tabular}


Furthermore, we evaluated the effect of various clinical and laboratory indicators on elevated Angll level with binary regression analysis. During the analysis, we applied Angll elevated or not as dependent variables, while applying the severity of COVID-19, gender, lymphocyte, PCT,CD4/CD8 cells ratio,CD3 + CD8 + cells count, CD3 + CD8 + cells proportion, CD56 + CD16 + CD3- cells count as independent variables, among these independent variables. The results showed that the severity of COVID-19 [OR $=4.123,95 \% \mathrm{CI}(1.07-15.877) \square \mathrm{p}=0.040]$ and $\mathrm{CD} 4 / \mathrm{CD} 8$ ratio[OR $=4.050,95 \% \mathrm{Cl}(1.207-13.588), \mathrm{p}=0.024]$ was the co-directional impact factor while female[OR $=0.146,95 \% \mathrm{Cl}(0.035-0.603) \square p=0.008]$ were reverse impact factor of elevated Angll level(depicted in Fig. 1).

\section{Discussion}

As COVID-19 outbreak continues to spread globally,the newly discovered infectious disease may cause global public health crisis. It was reported that on February 28th, the World Health Organization raised the global risk of transmission and impact of COVID-19 to "very high" level ${ }^{12}$. Although some literatures have been published, as a new epidemic infectious disease, the epidemiological and clinical characteristics of COVID-19 are not well known. Human ACE2 is confirmed to be the receptor and a gateway for SARS-CoV-2 ${ }^{6}$. ACE2 is a zinc metalloproteinase homologous to ACE, which can directly convert Ang II to Ang-(1-7), thus acting as a negative regulator of the renin-angiotensin system. Therefore, it could be hypothesized that a decrease in ACE2 caused by SARS-CoV-2 infection will reduce the degradation of Ang II, thereby causing an increase in Ang $\|^{8-9}$. A recently published small sample study not only confirmed this hypothesis, but also found that angiotensin II levels were linearly associated to viral load and lung injury in COVID-19 ${ }^{10}$. This study reported a high rate of increased level of Angll in COVID-19 patients, which could be verified with the study above. There was no significant difference in the history of hypertension and the use of vasoactive drugs such as norepinephrine and dopamine in the two groups, which means that abnormality of Angll cannot be blamed to a history of hypertension and the use of vasoactive drugs.

This study showed a significant difference in the severity of COVID-19 in the elevated Angll group, and the severity of COVID-19 was a risk factor of increased Angll level. When grouped according to disease severity, Angll was remarkably higher in critically ill patients than those with mild disease. That implied that Angll level was closely related to disease severity.

Furthermore, this study found that the level of blood lymphocyte, CD3 + CD 8 + cells, CD 56 + CD16 + CD3- cells, CD $3+$ CD 8 + cells proportion were dramatically lower and the CD4/CD 8 cells ratio was higher in the elevated Angll group than the normal Angll group. In addition, CD4/CD8 cells ratio was a risk factor of increased Angll level. As we know, CD3 + CD8 + cells, CD56 + CD16 + CD3- cells are killer cells that can recognize and eliminate virus-infected cells. This finding suggested that elevated Angll level may be associated with a reduction in killer cells. Accumulating evidences showed that CD $8+T$ cells are mediators of hypertension. hypertension in response to Angll treatment was reduced by 50\% in Cd8-/- mice ${ }^{13-15}$. These studies may provide clues to explain the finding that there was no statistically significant difference in the proportion of new hypertension in the two groups grouped by angiotensin levels. In addition, According to literature reports and our clinical observations, patients with COVID-19 often suffer from immune disorders and even immune storms ${ }^{16}$. What role Angll plays in immune disorders in COVID-19 needs further concern. 
There is no gender difference in the mean baseline values for plasma Ang II among normal population ${ }^{17}$. However, this study revealed significant gender differences in the mean baseline values for plasma Ang II among COVID-19 patients. Since ACE2 gene is located on the X chromosome, and estrogen increases ACE2 expression, ACE2 expression is higher in female than male ${ }^{18}$.Considering the gender differences in ACE2 expression, the gender differences in Angll level might deduce less loss of ACE2 in female patients. However, the exact mechanism needs to be further explored.

\section{Conclusion}

In summary,high rate of increased level of Angll was detected in COVID-19 patients. Angll level seemed to relevant to the severity of the disease, gender differences and immune disorder. This study was a single-center, retrospective analysis of a small sample with many confounding factors. Therefore, the conclusions above need to be verified by strict prospective or experimental research.

\section{Declarations}

\section{Authors' contributions}

Heng-Mei Zhu was responsible for the conception and design, analysis and assembly of data as well as interpretation, financial support and manuscript writing. Na Liu was responsible for the application for this study, the collection of data and manuscript writing. Yan Hong was responsible for the collection and analysis of data. Ren-Gui Chen was responsible for the application for this study and data collection. Na Liu and Yan Hong contributed to the work equally. Everyone participated in the final approval of the manuscript.

Funding Statement: This work was supported by Basic Research Project of Shenzhen Science and Technology Innovation Commission (JCYJ20160429181842402).

\section{Role of the funding source}

The funder of the study had no role in study design, data collection, data analysis, data interpretation, or writing of the report. The corresponding authors had full access to all the data in the study and had final responsibility for the decision to submit for publication.

\section{Availability of data and materials}

The datasets generated and analysed for this study are available from the corresponding author upon reasonable request.

\section{Ethics approval and consent to participate}

The study was approved by the ethics committee of Renmin Hospital of Wuhan University(Application IDQ [WDRY2020-K114]). In view of the fact that this study was conducted during the epidemic, Wuhan traffic was blocked at that time, and the subjects had been discharged from the hospital or were treated in isolation, this study was unable to sign an informed consent form with the subjects. The research does not involve personal 
privacy or commercial interests, and there is no risk to the test subjects. Based on the above circumstances, we had applied for exemption from the informed consent of the subjects from the ethics committee of Renmin Hospital of Wuhan University.

\section{Consent for publication}

Not applicable.

\section{Competing interests}

The authors declare that they have no competing interest.

\section{Acknowledgements}

We would like to thank all patients with COVID-19 who provided us with biological specimens for free. These patients gave us the courage and motivation to fight the disease. We are grateful to all the medical staff who treated patients with COVID-19 for their selfless dedication.

\section{Abbreviations}

COVID-19: 2019 Novel coronavirus disease; Angll: Angiotensin Il; Angiotensin-converting enzyme 2: ACE2; SARS-Cov-2: Severe acute respiratory syndrome coronavirus 2; AT1R: angiotensin II type 1 receptor; RT-PCR: real-time reverse-transcriptase polymerase-chain-reaction; IQR: Interquartile range; PaO2: alveolar oxygen partial pressure; FiO2: Fraction of inspiration 02; ALD: aldosterone; AARR: aldosterone/ Renin ratio; Ly: Lymphocyte; HB: Hemoglobin; PLT: Platelet count; CRP: C-reactive protein; PCT: Procalcitonin; BUN: Blood urea nitrogen; sCr: serum creatinine; ALT :Aspartate aminotransferase; AST: Alanine aminotransferase; ALB: albumin; LDH区lactate dehydrogenase; CK: Creatinine kinase; DD:D-dimer; APTT: Activated partial thromboplastin time; CD: cluster of differentiation; CD3+ count: CD3 positive cells count; CD3+CD4+ count: CD3 positive CD4 positive cells count; CD3+CD8+ count: CD3 positive CD8 positive cells count; CD4+/CD8+: CD4+/CD8+ ratio; CD56+CD16+CD3- count: CD56 positive CD16 positive CD3 negtive cells count; CD19+CD3count: CD19 positive CD3 negtive cells count; Ang-(1-7): Angiotensin-(1-7)

\section{References}

1. Wang C, Horby PW, Hayden FG, Gao GF. A novel coronavirus outbreak of global health concern [published correction appears in Lancet. 2020 Jan 29]. Lancet. 2020;395(10223):470-473. doi:10.1016/S01406736(20)30185-9.

2. Huang C, Wang Y, Li X, et al. Clinical features of patients infected with 2019 novel coronavirus in Wuhan, China [published correction appears in Lancet. 2020 Jan 30]. Lancet. 2020;395(10223):497-506. doi:10.1016/S0140-6736(20)30183-5.

3. Li Q, Guan X, Wu P, et al. Early Transmission Dynamics in Wuhan, China, of Novel Coronavirus-Infected Pneumonia [published online ahead of print, 2020 Jan 29]. N Engl J Med. 2020;10.1056/NEJMoa2001316. doi:10.1056/NEJMoa2001316. 
4. China National Health Commission. March 17th, 2020, update on the novel coronavirus pneumonia outbreak. Beijing: National Health Commission of the People's Republic of China, 2020.

http://www.nhc.gov.cn/xcs/yqtb/202003/97b96f03fa3c4e8d8d0bf536271a10c0.shtml.(check at 3.18).

5. WHO. Coronavirus disease 2019 (COVID-19) Situation Report - 57. Data as reported by 10 AM CET 17 March 2020. https://www.who.int/docs/default-source/coronaviruse/situation-reports/20200317-sitrep57-covid-19.pdf?sfvrsn=a26922f2_4. (check at 3.18)

6. Letko M, Marzi A, Munster V. Functional assessment of cell entry and receptor usage for SARS-CoV-2 and other lineage B betacoronaviruses. Nat Microbiol. 2020;5(4):562-569. doi:10.1038/s41564-020-0688-y.

7. Wan Y, Shang J, Graham R, Baric RS, Li F. Receptor recognition by novel coronavirus from Wuhan: An analysis based on decade-long structural studies of SARS [published online ahead of print, 2020 Jan 29]. J Virol. 2020;JVI.00127-20. doi:10.1128/JVI.00127-20.

8. Santos RAS, Sampaio WO, Alzamora AC, et al. The ACE2/Angiotensin-(1-7)/MAS Axis of the ReninAngiotensin System: Focus on Angiotensin-(1-7). Physiol Rev. 2018;98(1):505-553. doi:10.1152/physrev.00023.2016.

9. Arendse LB, Danser AHJ, Poglitsch M, et al. Novel Therapeutic Approaches Targeting the ReninAngiotensin System and Associated Peptides in Hypertension and Heart Failure. Pharmacol Rev. 2019;71(4):539-570. doi:10.1124/pr.118.017129.

10. Liu Y, Yang Y, Zhang C, et al. Clinical and biochemical indexes from 2019-nCoV infected patients linked to viral loads and lung injury. Sci China Life Sci. 2020;63(3):364-374. doi:10.1007/s11427-020-1643-8.

11. China National Health Commission. the Diagnosis and Treatment Scheme for New Coronavirus Pneumonia ( Pilot Edition 5囚Revised version). Beijing: National Health Commission of the People's Republic of China, February 8th, 2020.

http://www.nhc.gov.cn/yzygj/s7653p/202002/d4b895337e19445f8d728fcaf1e3e13a.shtml.

12. WHO.WHO Director-General's opening remarks at the media briefing on COVID-19 - 28 February 2020. https://www.who.int/dg/speeches/detail/who-director-general-s-opening-remarks-at-the-media-briefing-oncovid-19-28-february-2020.

13. Drummond GR, Vinh A, Guzik TJ, Sobey CG. Immune mechanisms of hypertension. Nat Rev Immunol. 2019;19(8):517-532. doi:10.1038/s41577-019-0160-5.

14. Trott, D. W. et al. Oligoclonal CD8+ T cells play a critical role in the development of hypertension. Hypertension 64, 1108-1115 (2014). doi: 10.1161/HYPERTENSIONAHA.114.04147.

15. Liu, Y. et al. CD8+ T cells stimulate Na-Cl co- transporter NCC in distal convoluted tubules leading to saltsensitive hypertension. Nat. Commun. 8, 14037 (2017). doi:10.1038/ncomms14037.

16. China National Health Commission. March 3rd, 2020, the Diagnosis and Treatment Scheme for New Coronavirus Pneumonia (Pilot Edition 7). Beijing: National Health Commission of the People's Republic of China, 2020.

17. Miller JA, Anacta LA, Cattran DC. Impact of gender on the renal response to angiotensin II. Kidney Int. 1999;55(1):278-285. doi:10.1046/j.1523-1755.1999.00260.x.

18. Te Riet $L$, van Esch JH, Roks AJ, van den Meiracker AH, Danser AH. Hypertension: renin-angiotensinaldosterone system alterations. Circ Res. 2015;116(6):960-975. doi:10.1161/CIRCRESAHA.116.303587. 


\section{Figures}

Figure 1: The effect of clinical and laboratory indicators on elevated Angll level with binary regression analysis

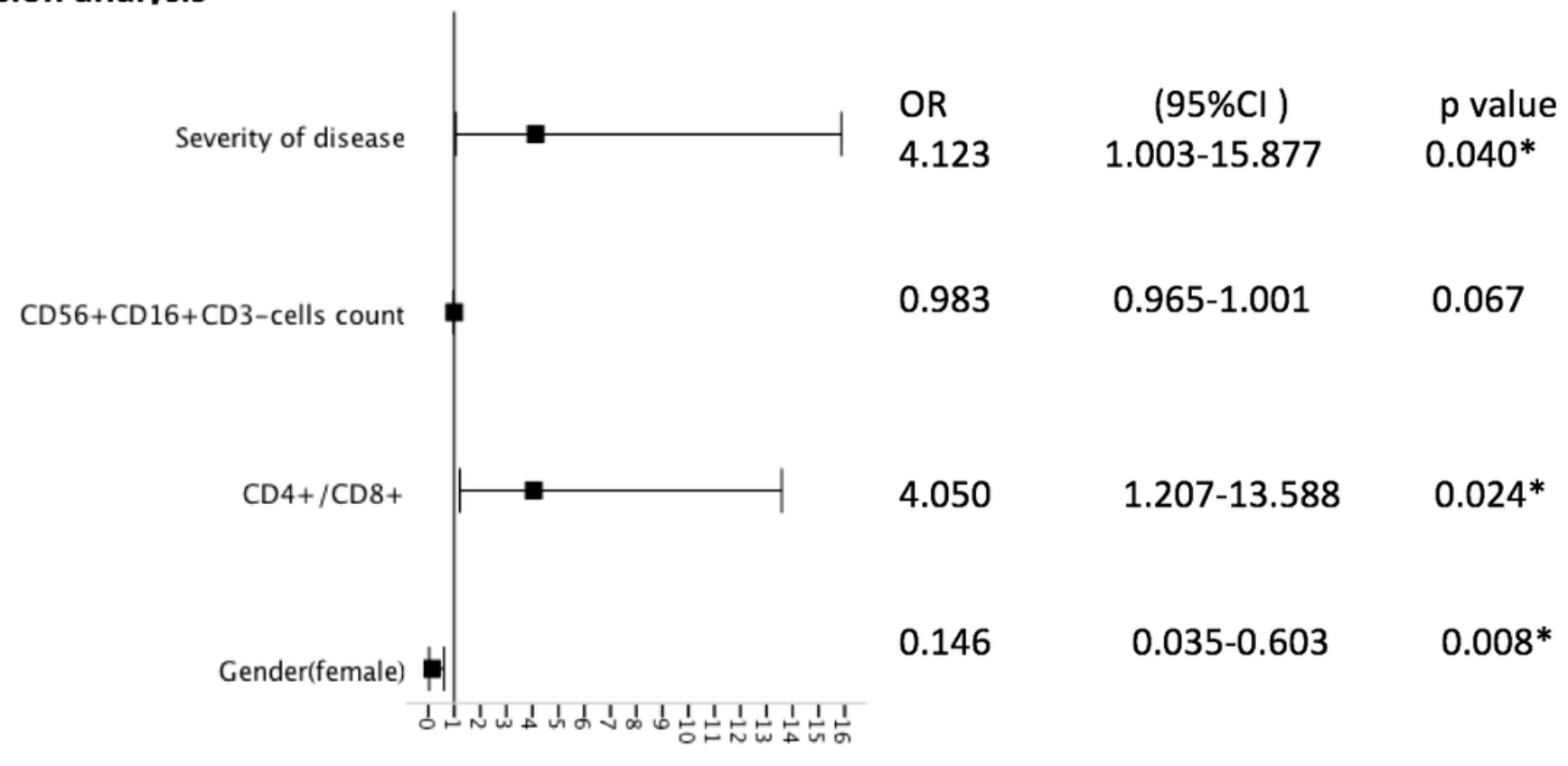

Figure 1

The effect of clinical and laboratory indicators on elevated Angll level with binary regression analysis 